\title{
PENGELOLAAN KOTA-KOTA KECIL DI JAWA TENGAH: STUDI KASUS PADA EMPAT KOTA KECIL DI WILAYAH JOGLOSEMAR
}

\author{
Governance and Planning of Small Towns in Central Java: \\ A Case Study from Four Small Towns in Joglosemar Region \\ Jawoto Sih Setyono ${ }^{1}$, Hadi Sabari Yunus ${ }^{2}$ dan Sri Rum Giyarsih ${ }^{3}$
}

Diterima: 22 Desember 2016

Disetujui: 31 Mei 2017

\begin{abstract}
Abstrak: Kota-kota kecil di Indonesia mengalami perkembangan yang cukup signifikan selama periode 2000-2010. Namun demikian, berkembangnya kota-kota kecil ini belum sejalan dengan perkembangan cara pengelolaan kota dan kawasan perkotaan. Ada kecenderungan pengelolaan kota-kota kecil belum menjadi perhatian serius pemerintah daerah, khususnya pada kawasan perkotaan yang tidak mempunyai status pemerintahan kota yang otonom. Penelitian ini menganalisis pengelolaan kota-kota kecil di Jawa Tengah dengan mengambil kasus di empat kota kecil pada wilayah koridor Joglosemar (YogyakartaSurakarta-Semarang). Penelitian ini dilakukan dengan metode kualitatif yang memadukan telaah dokumen, wawancara, dan analisis regulasi yang berhubungan dengan pengelolaan perkotaan. Dari hasil penelitian dapat disimpulkan bahwa terdapat kesenjangan antara perkembangan kota dengan pengelolaan perkotaan. Pengelolaan kota juga masih sangat bertumpu kepada pemerintah, meskipun terdapat permasalahan dalam kapasitas kelembagaan pengelolaan pembangunan kotanya.
\end{abstract}

Keyword in Bahasa: pengelolaan perkotaan, tata ruang, kelembagaan kota

\begin{abstract}
Small cities and towns in Indonesia have experienced a significant development during the period of 2000-2010. However, the development of small cities and towns has not been in line with the way the urban areas are governed and managed. There is a tendency that the governments pay a little attention to the governance of smaller urban areas, especially those which do not municipal status or the urban areas which is part of regency administrative boundary. This research analyzes the governance and planning of small towns in Central Java taken four small towns in Joglosemar region (Yogyakarta-Surakarta-Semarang). The research applied some qualitative methods combining document analysis, interview and regulation analysis. It is found that there is a significant gap between the urban development and its planning and governance. Urban development policies seem to be lacking in providing guidelines to drive the development of the small towns so that they can perform their functions within their respective regional urban system as well as solve their internal problems. The governance has mostly relied on the role of local government despite continuing lack of institutional capacity in managing urban development.
\end{abstract}

Keywords: urban governance, spatial development, institutional capacity

\footnotetext{
${ }^{1}$ Departemen Perencanaan Wilayah dan Kota, Fakultas Teknik, Universitas Diponegoro

${ }^{2}$ Fakultas Geografi, Universitas Gadjah Mada, Yogyakarta

${ }^{3}$ Fakultas Geografi, Universitas Gadjah Mada, Yogyakarta
} 


\section{PENDAHULUAN}

Kota kecil adalah tempat hidup bagi penduduk perkotaan, karena setengah dari penduduk perkotaan di seluruh dunia bertempat tinggal di kota-kota kecil ini (Tacoli ed., 2006). Jumlah penduduk kota kecil, yaitu kota-kota yang berpenduduk kurang dari 500.000 jiwa, adalah 25\% dari jumlah populasi dunia. Dari jumlah ini, hampir $50 \%$ berada di kawasan Asia (UN, 2015). Dengan kata lain, penduduk perkotaan di Asia umumnya berada pada kota-kota kecil ini. Untuk kasus Indonesia, sebagaimana yang diungkapkan dalam UN Population Division (2015), pada 2000 jumlah penduduk perkotaan yang bertempat tinggal di kota-kota kecil dengan ukuran kurang dari 500.000 jiwa adalah sebanyak 68\% dari jumlah populasi perkotaan secara keseluruhan. Proporsi ini meningkat jika dibandingkan dengan kondisi pada tahun 1980, di mana ada sekitar 57\% penduduk perkotaan berdiam pada kota-kota kecil ini.

Data sensus juga menunjukkan bahwa laju perkembangan penduduk perkotaan pada kota-kota kecil di Indonesia lebih tinggi dibandingkan dengan laju pertumbuhan penduduk pada kota-kota besar. Sebagaimana ditunjukkan oleh Firman dkk. (2007), laju pertumbuhan penduduk perkotaan di banyak kabupaten di Pulau Jawa lebih tinggi dari kota-kota yang selama ini menjadi rujukan kajian urbanisasi di Indonesia seperti Jakarta, Bandung, dan Surabaya. Dalam konteks ini, beberapa kabupaten di Jawa Tengah, dalam kurun waktu 1980-1990, bahkan menunjukkan tingkat urbanisasi yang sangat pesat, seperti misalnya Sukoharjo $(27,64 \%)$, Klaten $(10,22 \%)$, Jepara $(16,12 \%)$, dan Tegal $(16,0 \%)$ (Mardiansjah, 2007). Fakta ini menunjukkan bahwa selain fenomena urbanisasi yang mengarah kepada terbentuknya extended mega-urban regions seperti yang dikemukakan oleh Ginsburg dkk. (1991), proses urbanisasi juga terjadi pada wilayah yang bercirikan pedesaan. Fenomena ini sering disebut sebagai rurbanisasi sedangkan Mardiansjah (2007) menyebut fenomena ini sebagai "urbanisasi wilayah" (regional urbanization). Proses ini juga mengakibatkan munculnya extended urbanization pada perkotaan kecil, seperti yang terjadi di Cirebon dan sekitarnya (Fahmi dkk., 2014).

Perkembangan ini belum direspon dengan baik dalam kebijakan pembangunan perkotaan di Indonesia. Sejarah penataan ruang perkotaan di Indonesia lebih menekankan pada sisi perencanaan tata ruang, namun kurang memberikan perhatian pada pengelolaan kota (lihat misalnya di Renyasih, 2003; van Roosmalen, 2005). Meskipun pada tataran konseptual Indonesia mengalami pergeseran dari master urban planning menuju kepada manajemen perkotaan dan akhirnya pada tata kelola perkotaan (urban governance) seperti halnya negara berkembang lainnya (Devas dan Rakodi, 1991; van Dijk, 2003), dalam praktek perubahan ini tidak banyak terlihat pada kota-kota kecil, meskipun kota-kota ini menghadapi tantangan yang tidak kalah besarnya dibandingkan dengan kota-kota besar.

Ada beberapa tantangan yang dihadapi oleh kota kecil di Indonesia. Pertama, sebagian besar kota kecil di Indonesia tidak mempunyai "pemerintahan" sendiri (Nas, 1990; Malo dan Nas, 1991; Niessen, 1999). Adanya celah dalam pemerintahan tersebut berakibat pada banyak permasalahan kota, khususnya permasalahan tata ruang yang tidak tertangani dengan baik. Kedua, keberadaan kota besar yang berdekatan dengan kota-kota kecil memberikan pengaruh terhadap perkembangan kotanya. Sebagai akibatnya, kota-kota kecil cenderung tidak berkembang secara mandiri sebagai pusat permukiman (Firman, 2016). Ketiga, urusan pembangunan tidak efektif, khususnya pada kota kecil yang tidak menjadi pusat pemerintahan atau ibukota kabupaten. Problematika ini menyangkut tantangan kelembagaan (institutional challenges). Karena rentang kendali yang menjadi kewenangan pemerintahan kabupaten sangat besar, seringkali pelaksanaan urusan pembangunan pada kota kecil yang bukan merupakan ibukota kabupaten menjadi kurang efektif.

Ada perbedaan pandangan mengenai pengelolaan kota kecil. Pengelolaan kota kecil di negara-negara maju telah mendapatkan perhatian sejak lama. Di Amerika Serikat, 
perhatian terhadap kota kecil ini tercermin dengan adanya skema micropolitan dalam numenklatur kota-kota di negara tersebut. Mikropolitan ini mengacu pada sebuah sistem pengklasifikasian kota di luar kota besar (atau metropolitan), yaitu kota dengan jumlah penduduk relatif kecil, kurang dari 100.000 jiwa (Pacione, 2009). Kota kecil mendapatkan perhatian karena mempunyai peranan dalam pembangunan ekonomi serta penyediaan fasilitas dan infrastruktur dasar bagi penduduk yang mendiami kota tersebut. Dengan mempertimbangkan realitas tersebut skema pengendalian pertumbuhan (growth management) yang menjadi salah satu paradigma pembangunan perkotaan besar di Amerika Serikat juga diberlakukan bagi kota-kota kecil (Brower et al., 1984).

Berbeda dengan kondisi negara maju sebagaimana disebutkan sebelumnya, pengelolaan kota kecil di negara berkembang masih menjadi sesuatu yang diabaikan (Setyono, 2011; Ofori-Amoah, 2007; Bell dan Jayne, 2006; Bell dan Jayne, 2009). Selain karena adanya pengabaian tersebut, kondisi ini berhubungan juga pendekatan yang tidak tepat dalam mengelola persoalan yang muncul pada kawasan perkotaan, bukan saja pada kota kecil tetapi juga pada kota-kota besar. Kerangka perencanaan di NSB umumnya merupakan warisan kolonial dalam bentuk rencana induk (master planning). Sebagaimana yang dikemukakan oleh Rakodi (2001) perencanaan induk cenderung mengabaikan ketersediaan sumberdaya serta mekanisme implementasi, khususnya pada konteks lingkungan yang mempunyai banyak kendala. Kekurangan dalam dua hal tersebut telah menjadikan perencanaan sangat jauh dari problematika yang terjadi dalam kenyataan (Balbo, 1993). Sebagai akibatnya, terjadi kesenjangan (gap) yang cukup besar antara perencanaan dengan pembangunan di dalam praktek.

Dengan latar belakang tersebut, ada satu pertanyaan tentang bagaimana kota-kota kecil di Indonesia dikelola. Secara lebih spesifik, ada dua pertanyaan lanjutan yang ingin dijawab dalam artikel ini, yakni:

- Apa saja bentuk-bentuk pengelolaan yang telah dilakukan dan bagaimana hasilnya?

- Apakah model pengelolaan yang sekarang terjadi mampu mengarahkan perkembangan kotanya?

Penelitian ini dilakukan di Jawa Tengah dengan mengambil kasus pada wilayah koridor Semarang-Yogyakarta-Surakarta (wilayah Joglosemar). Kota kecil yang dijadikan sebagai unit analisis berada di empat wilayah kabupaten, yaitu Semarang, Boyolali, Klaten dan Magelang. Pemilihan wilayah koridor ini didasari pada pertimbangan bahwa pola urbanisasi pada wilayah Joglosemar cukup beragam. Di satu sisi terdapat wilayah yang mengalami urbanisasi yang sangat pesat seperti Klaten (Giyarsih, 2010), namun pada sisi lainnya terdapat kota yang mengalami pertumbuhan penduduk negatif seperti Yogyakarta (Firman, 2016). Kota Semarang sendiri sebagai pusat pertumbuhan di bagian tengah Pulau Jawa relatif lebih lambat perkembangannya dibandingkan dengan kota metropolitan lain di Pulau Jawa (Firman, 2016).

Artikel ini dibagi menjadi menjadi lima bagian. Bagian pertama memberikan penjelasan mengenai latar belakang dilakukannya penelitian yang melandasi artikel ini. Pada bagian kedua didiskusikan telaah literatur yang menjadi kerangka teoritik penelitian. Bagian ketiga menjelaskan metode dan data yang digunakan dalam analisis. Hasil pembahasan akan tercantum dalam bagian keempat. Bagian kelima berisi ringkasan, kesimpulan serta implikasi bagi perumusan kebijakan pengelolaan kota kecil di Indonesia umumnya dan Jawa Tengah khususnya.

\section{DATA DAN METODE}

Data pengelolaan kota bersumber dari dokumen kebijakan atau dokumen studi kebijakan. Dokumen kebijakan dalam hal ini adalah dokumen Rencana Tata Ruang Wilayah Kabupaten (RTRWK) pada empat kabupaten yang menjadi unit amatan. Keempat dokumen RTRWK telah menjadi dokumen yang secara hukum mengikat karena telah 
dituangkan dalam bentuk Peraturan Daerah. Dokumen studi kebijakan berupa hasil kajian perencanaan tata ruang pada kota-kota kecil yang menjadi unit amatan di empat kabupaten. Berbeda dengan dokumen RTRW, dokumen perencanaan ini masih belum mempunyai basis legal, meskipun dalam prakteknya seringkali dijadikan rujukan dalam mengarahkan dan menyusun kebijakan pembangunan kota (Wawancana terhadap staf kunci Bappeda di empat kabupaten, 2015). Selain data pengelolaan kota, penelitian ini juga menggunakan data sekunder yang berasal dari Badan Pusat Statistik, Bappeda, dan Kantor Kecamatan. Data sekunder ini berhubungan dengan indikator perkembangan kota.

Beberapa kegiatan wawancara dilakukan sebagai upaya melengkapi dan memperoleh informasi tambahan. Wawancara dilakukan untuk menggali informasi, pengalaman, serta problematika pengelolaan perkembangan kota. Dalam penelitian ini, wawancara bukan menjadi instrumen pokok dalam penelitian ini karena sifatnya hanya melengkapi hasil kajian dokumen dan analisis data sekunder. Wawancara dilakukan terhadap pelaku pokok pembangunan pada tingkat kecamatan, yaitu Kepala Kecamatan atau Camat. Wawancara dilakukan secara tidak terstruktur dan dalam prakteknya juga melibatkan aparatur lain pada tingkat pemerintahan kecamatan, seperti Sekretaris Kecamatan dan Kasi Pembangunan.

Selain wawancara, pengumpulan data juga dilkaukan melalui pengamatan terhadap proses perumusan kebijakan dalam forum Musrenbang (Musyawarah Perencanaan Pembangunan) tingkat kecamatan. Kegiatan ini dilakukan dengan tujuan untuk mengetahui permasalahan aktual yang terjadi di kota-kota kecil dalam unit amatan. Penggalian informasi melalui pengamatan terhadap kegiatan Musrenbang yang dilakukan di empat kecamatan pada kurun waktu Februari 2016.

Analisis pengelolaan perkotaan dilakukan dengan teknik kualitatif melalui telaah dokumen, yang meliputi dokumen rencana dan dokumen regulasi yang menjadi basis normatif pengelolaan perkotaan. Kajian ini dilengkapi dengan pendalaman terhadap informasi yang diperoleh dari proses Musrenbang dan wawancara terhadap pimpinan pemerintahan tingkat kecamatan. Analisis ini bertujuan untuk mengetahui bagaimana pengelolaan perkotaan yang terjadi dalam praktek.

\section{HASIL DAN PEMBAHASAN}

\section{Kerangka Teoritik Pengelolaan Perkotaan}

Davidson (1996) berpendapat bahwa terjadinya perbedaan yang besar antara yang direncanakan dengan hasil pembangunan karena tiadanya beberapa mekanisme transisi yang menghubungkan rencana dengan pembangunan. Karena perencanaan kota dianggap tidak efektif, muncul konsep manajemen perkotaan sebagai respon kegagalan perencanaan tersebut (Devas dan Rakodi, 1993; lihat juga Keiner, 2005). Manajemen perkotaan (urban management) ini dianggap sebagai jawaban terhadap gagalnya perencanaan perkotaan dalam merespon fenomena urbanisasi beserta permasalahannya. Manajemen perkotaan diartikan sebagai serangkaian aktivitas yang menciptakan dan mendukung keberlangsungan perkembangan ekonomi, fisik dan sosial dalam suatu wilayah perkotaan (McGill (1998). Konsep manajemen perkotaan ini lebih bersifat sektoral dan fokus pada penyelesaian masalah perkotaan dalam jangka pendek.

Dalam perkembangannya, muncul konsep tata kelola perkotaan (urban governance) yang dianggap sebagai pelengkap terhadap kekurangan konsep perencanaan dan manajemen perkotaan. Tata kelola perkotaan pada dasarnya merupakan sebuah proses kolaboratif dalam pengambilan keputusan serta koordinasi yang efektif antara pemerintah lokal, organisasi kemasyarakatan dan pihak swasta dalam usahanya untuk mencapai pembangunan perkotaan yang berkelanjutan dan berbasis demokrasi lokal (Pieterse, 2000). Lebih lanjut, tata kelola perkotaan juga dipandang sebagai respon yang efektif dan efisien 
terhadap permasalahan perkotaan melalui kerjasama antara masyarakat pada umumnya dengan pemerintah lokal (Pieterse, 2000).

Pengelolaan kota sebagai sebuah konsep seringkali disamakan dengan dua konsep yang muncul dalam literatur, yakni manajemen kota (urban management) dan tata kelola perkotaan (urban governance). Manajemen kota sebagai sebuah wacana akademik muncul dalam literatur studi perkotaan dan perencanaan pada akhir 1980an. Menurut ObengOdoom (2012), munculnya konsep baru ini merupakan kontribusi Bank Dunia bekerja sama dengan lembaga PBB UN Habitat dengan program Program Manajemen Kota (UMP - Urban Management Programme) yang dirancang untuk mengatasi permasalahan yang muncul akibat perkembangan kota yang pesat di negara sedang berkembang. Program ini berakhir pada akhir 1990an dan kemudian diganti dengan program tata kelola kota, yang dikenal hingga saat ini sebagai konsep dan wacana teoretis pembangunan kota (ObengOdoom, 2012). Berbeda dengan manajemen kota yang lebih mengarah kepada proses pembangunan ekonomi dan fisik, tata kelola lebih banyak menggagas tentang bagaimana para pemangku kepentingan (stakeholders) berpartisipasi pada proses pembangunan dan perumusan kebijakan.

Pengelolaan kota dalam penelitian ini menggabungkan kedua konsep tersebut. Dalam pengertian yang lebih praktis, pengelolaan kota dalam hal ini dipahami sebagai upaya untuk mengarahkan pembangunan kota sebagai respon terhadap perkembangan yang terjadi pada kawasan perkotaan. Upaya pengarahan ini bisa dalam bentuk perencanaan, khususnya perencanaan tata ruang, serta pembangunan kota yang bisa bersifat multisektor. Dengan demikian, sebagaimana dikemukakan oleh Davidson (1996), pengelolaan kota merupakan upaya dan cara (means) untuk membangun kota dan mewujudkan perencanaan dalam bentuk alokasi sumber daya dengan berbagai saluran pembangunan yang mungkin (lihat Gambar 1). Dalam pandangan ini, unsur proses pembangunan yang menjadi inti konsep manajemen kota tercakup; demikian juga unsur keterlibatan masyarakat dalam proses pembangunan.

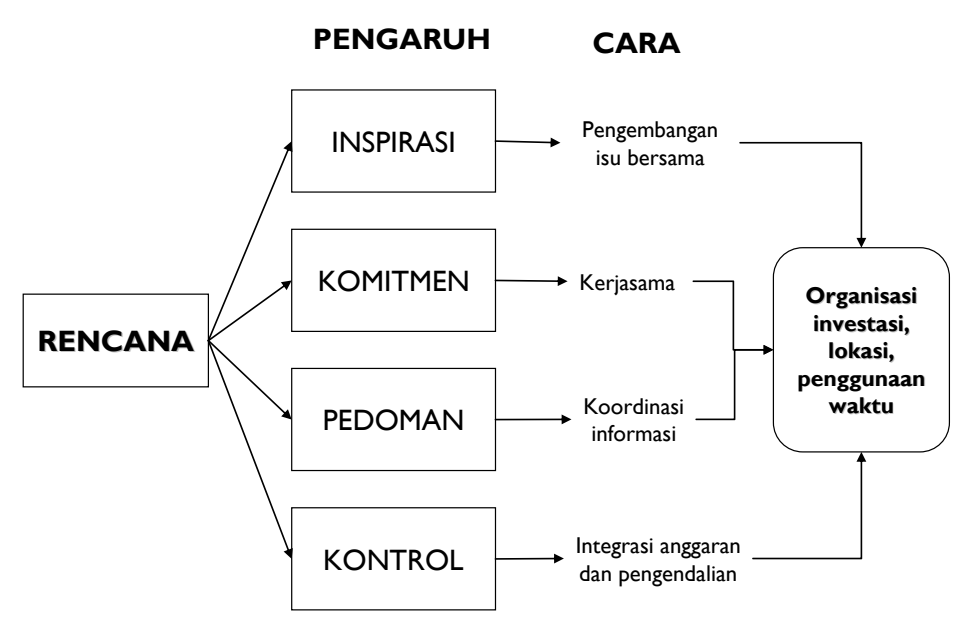

Sumber: Davidson, 1996: 450

Gambar 1 Pengaruh Rencana terhadap Pembangunan Perkotaan

Davidson (1996) berargumentasi bahwa perencanaan akan memberikan hasil yang baik jika dilakukan melalui berbagai macam saluran, tidak saja melalui mekanisme yang didominasi oleh kewenangan yang menjadi domain pemerintah semata. Level pengaruh tersebut bisa pada individu melalui inspirasi maupun melalui mekanisme kontrol yang ketat 
dari pemerintah. Ini hanya bisa terjadi bila ada tata kelola yang baik di mana setiap aktor tahu apa yang diperbuatnya dan terlibat dalam proses pembangunan perkotaan. Di samping itu, perbaikan harus juga dilakukan pada sisi perencanaan. Dengan adanya perubahan ini, maka dokumen perencanaan akan menjadi dasar bagi pelaksanaan pembangunan yang sesuai dengan perencanaan.

Lebih lanjut Davidson (1996) menjelaskan bahwa rencana harus dikembangkan menjadi beberapa kegiatan agar rencana tersebut mempunyai kekuatan pengaruh bagi terciptanya kegiatan pembangunan, atau implementasi rencana. Dengan kata lain, agar rencana tidak hanya sekadar dokumen, maka perlu upaya agar rencana itu bisa menjadi 4 (empat elemen kunci) yang berpengaruh. Keempat elemen kunci tersebut adalah: 1). inspirasi; 2) komitmen; 3) pedoman; dan 4) kontrol atau pengendalian (lihat Gambar 1). Keempat elemen ini menurut Davidson (1996: 450) mewakili "a range of relationships that a plan can have with the key stakehoders."

\section{Kerangka Formal Pengelolaan Kawasan Perkotaan}

Pengelolaan perkotaan di Indonesia tidak bisa dilepaskan dari urusan pemerintahan secara umum serta sistem pemerintahan yang berlaku pada masanya. Berdasarkan pandangan ini, pengelolaan perkotaan di Indonesia seharusnya diletakkan dalam konteks penyelenggaraan pemerintahan. Dalam penyelenggaraan pemerintahan, Indonesia mengalami banyak perubahan sejak terbentuknya Negara Kesatuan Republik Indonesia yang merdeka pada 17 Agustus 1945. Pada periode pasca kemerdekaan memang terdapat beberapa undang-undang yang mengatur sistem pemerintahan daerah atau otonomi daerah pada era pasca kemerdekaan, namun kondisi politik yang belum stabil menyebabkan sistem pemerintahan secara keseluruhan belum bisa berfungsi secara nyata seperti yang diinginkan dalam undang-undang tersebut (lihat Harsono, 1992; Niessen, 1999). Selain berkaitan dengan sistem pemerintahan daerah, pengelolaan perkotaan juga terkait dengan penataan ruang, sebuah istilah baru yang berlaku di Indonesia yang setara dengan urban and regional planning atau spatial planning dalam bahasa Inggris (van Roosmalen, 2005).

Pengelolaan kawasan perkotaan yang berada di bawah jurisdiksi wilayah kabupaten mulai tercantum dalam sebuah undang-undang untuk pertama kalinya ketika UU 22/1999 tentang Pemerintahan Daerah disahkan. Dengan adanya Undang-undang Pemerintahan Daerah yang baru ini bersama dengan UU 25/1999 tentang Perimbangan Keuangan antara Pemerintah Pusat dan Pemerintah Daerah, Indonesia dinilai telah melakukan lompatan besar tidak saja dalam sistem pemerintahan tetapi dalam pembangunan secara keseluruhan (Firman, 2003; Hill dan Vidyattama, 2016). Dalam hubungan dengan perkotaan, secara spesifik UU 22/1999 menyebut bagaimana kawasan perkotaan dikelola. Terdapat tiga pasal dalam Undang-undang tersebut yang berhubungan dengan pengelolaan kawasan perkotaan, di antaranya ada pernyataan tentang "Badan Pengelola Pembangunan" untuk kawasan perkotaan (UU 22/1999, Pasal 91) serta keikutsertaan swasta dan masyarakat dalam penyelenggaraan pembangunan kawasan perkotaan.

Penegasan mengenai pengelolaan kawasan perkotaan ini diperkuat lagi dengan adanya UU 32/2004 tentang Pemerintahan Daerah yang merupakan pengganti UU 22/1999. Sebagai tindak lanjut dari Undang-undang ini, pada 2009, pemerintah menerbitkan PP 34/2009 tentang Pedoman Pengelolaan Kawasan Perkotaan. Dalam regulasi yang baru ini, kawasan perkotaan yang berada di dalam batas administrasi kabupaten bisa dikelola oleh sebuah Lembaga Pengelola yang bersifat multi-stakeholder karena adanya keterlibatan pihak di luar pemerintah daerah. Sebagai sebuah pendekatan, apa yang diamanatkan dalam Peraturan ini merupakan sebuah paradigma baru yang cukup "revolusioner" karena membuka peluang lembaga nonpemerintah mengelola 
pembangunan kawasan perkotaan. Faktanya, walaupun secara regulasi peluang tersebut tersedia, sampai dengan terbitnya Undang-undang baru pengganti UU 32/2004 yaitu UU 23/2014 tentang Pemerintahan Daerah, bentuk nyata kelembagaan pengelolaan kawasan perkotaan tersebut tidak pernah ada.

Perubahan selanjutnya mengenai kawasan perkotaan ini muncul dalam UU 23/2014 mengenai Pemerintahan Daerah sebagai pengganti UU 32/2004. Dalam Undangundang ini, terdapat perubahan definisi mengenai kawasan perkotaan. Berbeda dengan sebelumnya, yang dimaksud dengan kawasan perkotaan adalah kawasan perkotaan alami yang berada dalam batas administrasi kabupaten atau kawasan perkotaan baru. Perbedaan ini juga berhubungan dengan cara pengelolaan kawasan perkotaan, karena kawasan perkotaan menjadi bagian dari urusan pemerintah daerah. Lembaga pengelola kawasan perkotaan masih diberi ruang, tetapi terbatas pada kawasan perkotaan baru (kawasan perkotaan terencana) yang dibangun oleh badan hukum. Baik badan hukum maupun pemerintah daerah diwajibkan untuk menyediakan fasilitas perkotaan sesuai dengan standar pelayanan minimum yang berlaku. Ketentuan-ketentuan dalam UU 23/2014 ini merupakan pendekatan baru dalam pengelolaan perkotaan yang berbeda dengan PP $34 / 2009$.

Dari penjelasan tersebut di atas dapat dipahami bahwa ada perubahan perhatian dan fokus terhadap kawasan perkotaan di dalam sistem peraturan di Indonesia. Perubahan ini tidak saja menyangkut ruang lingkup mengenai kawasan perkotaan, melainkan juga tentang perencanaan dan pengelolaannya. Tabel 1 dan Tabel 2 merangkum adanya perkembangan konsep kawasan perkotaan dan pengelolaan kawasan perkotaan di Indonesia. Perubahan pertama berhubungan dengan sistem perencanaan, di mana pada periode sebelum 2007, perencanaan kawasan perkotaan merupakan bagian intergral dari dokumen rencana tata ruang wilayah kabupaten/kota, sementara pada saat ini perencanaan kawasan perkotaan merupakan kegiatan tersendiri sebagai tindak lanjut dari rencana tata ruang wilayah kabupaten.

Tabel 1 Kawasan Perkotaan dan Aspek Perencanaan dalam UUPR

\begin{tabular}{lll}
\hline Aspek & UU 24/1992 & UU 26/2007 \\
\hline Pengertian & $\begin{array}{l}\text { kawasan yang mempunyai kegiatan } \\
\text { utama bukan pertanian dengan susunan } \\
\text { fungsi kawasan sebagai tempat } \\
\text { permukiman perkotaan, pemusatan dan } \\
\text { distribusi pelayanan jasa pemerintahan, } \\
\text { pelayanan sosial, dan kegiatan ekonomi }\end{array}$ & $\begin{array}{l}\text { wilayah yang mempunyai kegiatan } \\
\text { utama bukan pertanian dengan susunan } \\
\text { fungsi kawasan sebagai tempat } \\
\text { permukiman perkotaan, pemusatan dan } \\
\text { pelayanan sosial, dan kegiatan ekonomi }\end{array}$ \\
$\begin{array}{l}\text { Kedudukan dalam } \\
\text { penataan ruang }\end{array}$ & $\begin{array}{l}\text { penataan ruang berdasarkan fungsi } \\
\text { kawasan dan aspek kegiatan }\end{array}$ & $\begin{array}{l}\text { penataan ruang berdasarkan kegiatan } \\
\text { kawasan }\end{array}$ \\
$\begin{array}{l}\text { Keterkaitan dengan } \\
\text { RTRW }\end{array}$ & $\begin{array}{l}\text { bagian dari muatan substansi RTRW } \\
\text { provinsi dan RTRW kabupaten/kota }\end{array}$ & $\begin{array}{l}\text { rencana tersendiri, RTRW kawasan } \\
\text { perkotaan }\end{array}$ \\
Jenis rencana & - & Rencana rinci \\
Jangka waktu & & 20 tahun \\
rencana & 15 dan 10 tahun & \\
\hline
\end{tabular}

Sumber: Diolah dari UU 24/1992 dan UU 26/2007

Perubahan cara pandang juga terjadi pada aspek pengelolaan kawasan perkotaan. Secara kelembagaan pada era pasca reformasi sampai dengan 2014, terdapat kemungkinan kawasan perkotaan dikelola dengan cara yang sangat terbuka, di mana lembaga nonpemerintah bisa diberikan kewenangan dalam pengelolaan kawasan perkotaan. Hal 
yang berbeda terjadi setelah UU Pemerintah Daerah terakhir (UU 23/2014) mengembalikan pengelolaan kawasan perkotaan sebagai kewenangan pemerintah, meskipun lembaga nonpemerintah dalam bentuk badan hukum bisa membangun dan mengelola kawasan perkotaan baru. Kondisi ini seolah-olah menjadi era baru dalam pengelolaan perkotaan dan bisa menjadi tren di masa yang akan datang.

Tabel 2 Pengelolaan Kawasan Perkotaan dalam UU Pemerintahan Daerah

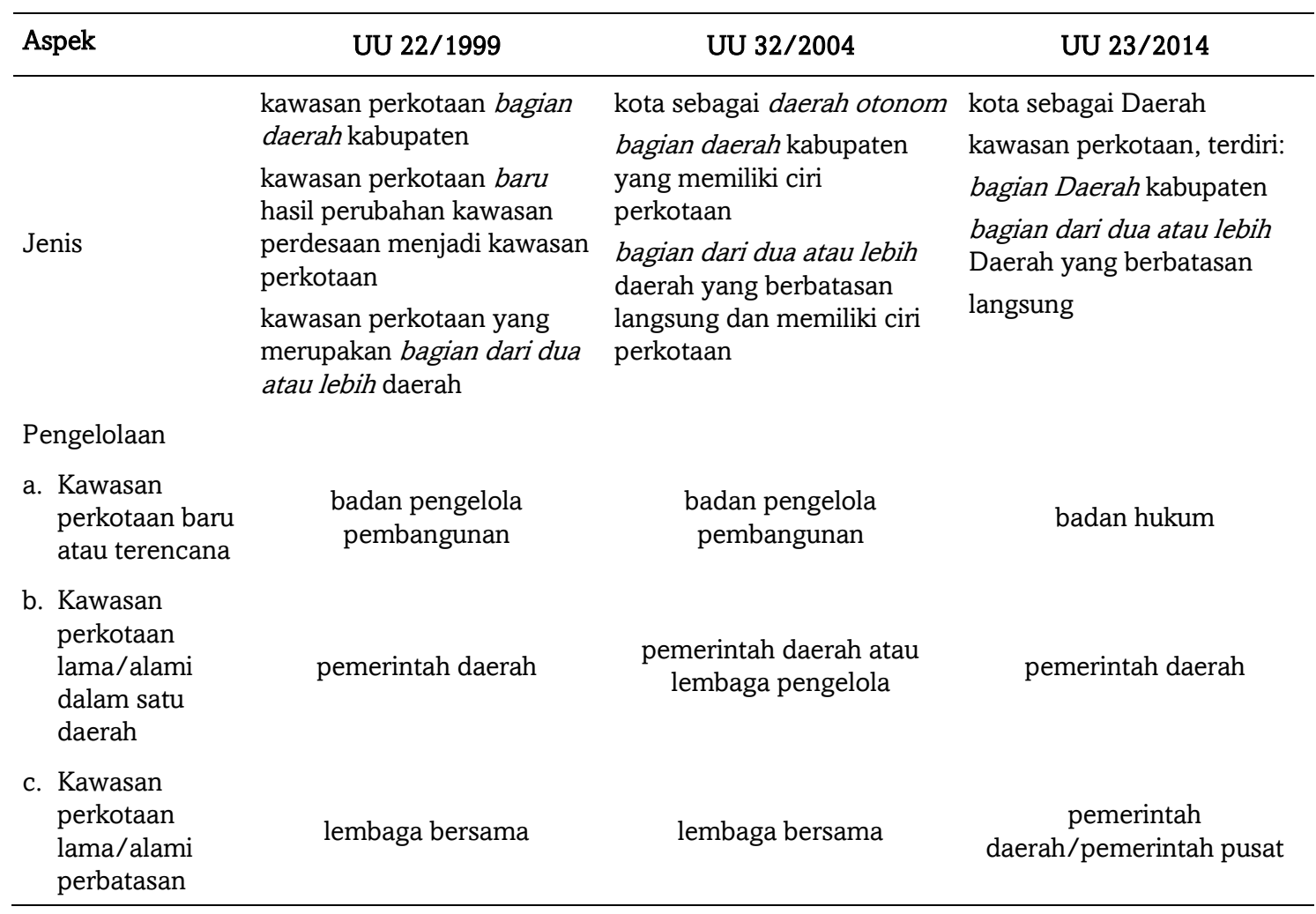

Sumber: Diolah dari UU Pemerintahan Daerah (22/1999. 32/2004, 23/2014)

\section{Kebijakan Pengelolaan Kota Kecil di Empat Kabupaten}

Kebijakan pengelolaan kota-kota kecil pada wilayah Joglosemar dapat dipahami salah satunya dari pengkajian terhadap dokumen perencanaan tata ruang wilayah. Ada dua dokumen perencanaan yang menjadi bahan kajian, yakni rencana tata ruang wilayah kabupaten dan dokumen perencanaan detil/rinci pada tingkat kecamatan atau kawasan perkotaan. Pada empat wilayah kabupaten yang diteliti, dokumen rencana tata ruang wilayah kabupaten sudah mempunyai kekuatan mengikat secara hukum karena sudah tertuang dalam Peraturan Daerah di masing-masing kabupaten. Sementara itu, dokumen rencana tata ruang kecamatan atau kawasan perkotaan masih dalam bentuk studi atau sedang dalam proses untuk diusulkan sebagai Peraturan Daerah atau Peraturan Bupati di masing-masing daerah.

Empat kabupaten (Semarang, Boyolali, Klaten, dan Magelang) melakukan kegiatan penyusunan dokumen Rencana Tata Ruang Wilayah Kabupaten pada 2010 dan melegalkan dokumen rencana tersebut ke dalam Peraturan Daerah (Perda) pada 2011, dengan nomor masing-masing adalah: (1) Semarang, Perda 6/2011; (2) Boyolali, Perda 9/2011; (3) Klaten, Perda 11/2011; dan (4) Magelang, Perda 5/2011. Pada saat ini, keempat dokumen rencana tata ruang tersebut sedang dalam proses peninjauan kembali dan revisi, untuk meyesuaikan dengan perkembangan yang terjadi dan kebutuhan pembangunan 
(Wawancara dengan staf Bappeda di empat kabupaten, 2015). Dalam sistem penyelenggaraan penataan ruang di Indonesia, sebagaimana diatur dalam UUPR, kegiatan peninjauan kembali (review)-revisi ini umumnya dilakukan pada masa lima tahun sejak dokumen RTRW dilegalkan melalui Perda.

Selain dokumen RTRW yang mengatur wilayah kabupaten secaran keseluruhan, pada empat kota kecil yang dikaji itu juga telah disusun dokumen perencanaan tata ruang, meskipun dilakukan pada tahun yang berbeda-beda. Kecamatan Ambarawa menyusun dokumen Rencana Detail Tata Ruang Ambarawa pada 2002 dan Peraturan Zonasi Kota Ambarawa pada 2011. Kecamatan Ampel di Boyolali mempunyai dokumen Rencana Detail Tata Ruang Kecamatan Ampel 2012-2032, pada 2011 dan saat ini sedang proses usulan menjadi Peraturan Daerah (Wawancara dengan Diana, staf Bappeda Boyolali, 2015). Sementara itu, di Klaten, Kecamatan Delanggu juga telah memiliki dokumen Rencana Detail Tata Ruang Delanggu 2012-2032 yang disusun pada 2011. Terakhir, Muntilan di Kabupaten Magelang menyusun dokumen Rencana Detail Tata Ruang Muntilan pada 2012. Secara keseluruhan, keempat dokumen perencanaan tersebut masih berupa studi perencanaan dan belum mempunyai dasar hukum yang kuat. Namun demikian, di dalam praktek dokumen-dokumen tersebut telah dijadikan rujukan dalam proses perumusan kebijakan yang berhubungan dengan pembangunan di masing-masing kecamatan, termasuk pemberian pertimbangan dalam proses penerbitan ijin pemanfaatan ruang (Wawancara dengan staf Bappeda di empat kabupaten, 2015).

Dalam dokumen rencana tata ruang wilayah kabupaten, keempat kota kecil itu diarahkan sebagai pusat kegiatan lokal (PKL). Pusat kegiatan lokal ini bermakna bahwa kota-kota ini menjadi pusat pelayanan bagi beberapa wilayah kecamatan di sekitarnya, selain sebagai pusat bagi penduduk yang bermukim di wilayahnya sendiri. Berbeda dengan tiga kawasan perkotaan lainnya, arah kebijakan untuk Ambarawa mencakup lebih banyak aspek. Kota Muntilan dan Delanggu selain berfungsi sebagai pusat kegiatan lokal juga ditetapkan sebagai kawasan strategis kabupaten, kawasan yang pengembangannya menjadi prioritas bagi pemerintah daerah. Secara keseluruhan, fungsi yang diarahkan kepada empat kota ini sama yakni sebagai pusat pelayanan (service center). Fungsi ini sejalan dengan pandangan Rutz (1987) mengenai salah satu ciri fungsi kota di Indonesia, yaitu sebagai pusat komersial (commercial center). Kota dengan fungsi sebagai pusat komersial ini menjadi pusat transaksi barang baik yang bersifat banyak (grosir, wholesale) mapun eceran (retai). Dengan kata lain, kota-kota yang menyandang fungsi ini berkembang sebagai tempat pasar (market place) di mana dinamika perkembangan kotanya akan sangat tergantung pada keberadaan pusat transaksi barang dan komoditas, umumnya komoditas pertanian.

Arahan fungsi kota yang tertuang dalam kebijakan pada tingkat kabupaten itu seharusnya mempunyai penjabaran secara lebih detil dalam dokumen perencanaan turunannya. Untuk melihat apakah ada konsistensi antara perencanaan makro dengan perencanaan detail, analisis yang lebih mendalam dilakukan terhadap setiap dokumen rencana detail tata ruang di empat kecamatan/kawasan perkotaan. Konsistensi antara rencana tata ruang wilayah kabupaten yang bersifat umum dengan rencana detail tata ruang yang bersifat rinci bisa dilihat dari berbagai cara. Cara yang pertama adalah dengan mendalami tujuan perencanaan. Pada dasarnya tujuan perencanaan merupakan pernyataan mengenai apa yang ingin dicapai oleh kota itu pada akhir tahun perencanaan atau merupakan gambaran akhir dari kegiatan perencanaan. Selain itu, tujuan perencanaan bisa menjadi panduan bagi tindakan-tindakan. Karena pentingnya elemen tujuan ini dalam perencanaan, penilaian terhadap "good planning" atau "good plan" sering dilakukan pada pernyataan tujuan, selain penilaian terhadap program dan hasil perencanaan (Talen, 1997; Oliveira dan Pinho, 2010; Fischler, 2012). 
Penilaian terhadap tujuan perencanaan empat kota kecil yang diteliti tersebut tercantum dalam Tabel 3. Di antara empat kota kecil, dokumen perencanaan tata ruang di Ambarawa tidak mengandung tujuan perencanaan, sementara tiga kota lain mempunyai rumusan tujuan perencanaan yang eksplisit. Ketiadaan rumusan tujuan perencanaan pada Kota Ambarawa ini kemungkinan terjadi karena rencana detail tata ruang pada kota ini disusun terlebih dahulu daripada rencana umumnya dan dilakukan dengan menggunakan skema regulasi lama, yakni UUPR 1992. Ketiga kota lainnya menyusun rencana detail tata ruang sebagai penjabaran dari rencana tata ruang wilayah kabupaten.

Tabel 3 Kebijakan Pengembangan Kota Kecil di Empat Kabupaten

\begin{tabular}{|c|c|c|c|c|}
\hline Kota & $\begin{array}{l}\text { Strategi penataan } \\
\text { ruang }\end{array}$ & $\begin{array}{l}\text { Kedudukan kota } \\
\text { dalam rencana } \\
\text { struktur ruang }\end{array}$ & $\begin{array}{l}\text { Arahan fungsi kota sebagai } \\
\text { pusat kegiatan }\end{array}$ & $\begin{array}{l}\text { Arahan } \\
\text { sektoral/kawasan } \\
\text { strategis }\end{array}$ \\
\hline Ambarawa & $\begin{array}{l}\text { meningkatkan } \\
\text { peran perkotaan } \\
\text { Ambarawa } \\
\text { sebagai pusat } \\
\text { kegiatan bagi } \\
\text { wilayah } \\
\text { sekitarnya }\end{array}$ & $\begin{array}{l}\text { pusat kegiatan } \\
\text { lokal (PKL) }\end{array}$ & $\begin{array}{l}\text { pusat pelayanan permukiman, } \\
\text { perdagangan dan jasa, pusat } \\
\text { pengembangan pariwisata, } \\
\text { pertanian, serta perikanan } \\
\text { skala beberapa Kecamatan di } \\
\text { sekitarnya }\end{array}$ & $\begin{array}{l}\text { kawasan wisata } \\
\text { berbasis budaya } \\
\text { kawasan strategis } \\
\text { kabupaten }\end{array}$ \\
\hline Ampel & - & $\begin{array}{l}\text { pusat kegiatan } \\
\text { lokal (PKL) }\end{array}$ & $\begin{array}{l}\text { kawasan perdagangan dan } \\
\text { jasa, industri, perekonomian } \\
\text { untuk skala regional, } \\
\text { pendidikan, kesehatan, } \\
\text { peribadatan }\end{array}$ & $\begin{array}{l}\text { kawasan } \\
\text { agropolitan }\end{array}$ \\
\hline Delanggu & - & $\begin{array}{l}\text { pusat kegiatan } \\
\text { lokal (PKL) }\end{array}$ & $\begin{array}{l}\text { kawasan perdagangan dan } \\
\text { jasa, permukiman perkotaan, } \\
\text { pariwisata, pertanian, industri, } \\
\text { pelayanan perekonomian dan } \\
\text { sosial untuk skala regional, } \\
\text { pendidikan, kesehatan, } \\
\text { perhubungan, dan peribadatan }\end{array}$ & $\begin{array}{l}\text { kawasan strategis } \\
\text { kabupaten, } \\
\text { pengembangan } \\
\text { fungsi kegiatan } \\
\text { utama } \\
\text { perdagangan, dan } \\
\text { permukiman } \\
\text { perkotaan }\end{array}$ \\
\hline Muntilan & - & $\begin{array}{l}\text { pusat kegiatan } \\
\text { lokal (PKL }\end{array}$ & - & $\begin{array}{l}\text { kawasan strategis } \\
\text { pertumbuhan } \\
\text { ekonomi }\end{array}$ \\
\hline
\end{tabular}

Sumber: Diolah dari Perda RTRW 4 kabupaten, 2016

Pendalaman terhadap pernyataan tujuan perencanaan atau penataan ruang di tiga kota yang diteliti mempu mengungkapkan fakta ketidakkonsintenan antara fungsi kota yang ditetapkan dalam rencana tata ruang wilayah dengan tujuan peencanaan di dalam dokumen rencana detail tata ruang kota (lihat Tabel 4). Pada kasus Kota Delanggu, pernyataan tujuan dalam RDTRK secara tersurat menegaskan pentingnya sektor pertanian sebagai basis bagi perekonomian wilayah, sedangkan arahan fungsi kota yang tercantum dalam RTRW menegaskan fungsi utama perdagangan sebagai kegiatan utama. Kondisi yang kurang lebih sama terjadi pada dua kota lainnya. Kota Muntilan disebut sebagai pusat pertumbuhan ekonomi, namun dalam dokumen rencana turunannya terdapat pernyataan tujuan yang beragam yang tidak secara langsung mendukung penetapan arahan fungsi kota. Shawma (2012) dalam hasil penelitiannya mengenai perencanaan tata ruang di Muntilan mengemukakan bahwa terdapat banyak perbedaan antara arahan rencana tata ruang level makro dengan rencana detail tata ruang. Lebih lanjut dikatakan bahwa 
perbedaan ini muncul karena proses perencanaan didominasi oleh metode pendekatan sinoptik sehingga dalam prakteknya sering bersifat isolatif terhadap adanya kebijakan lain.

Secara substansi produk rencana detail tata ruang pada empat kota kecil tersebut juga tidak menawarkan "kondisi yang lebih", sebuah prinsip dasar dan kriteria penting dalam perencanaan (Fischler, 2012). Sebagaimana dikemukakan oleh Fischler (2012), perencanaan yang baik harus mampu memperbaiki kondisi permukiman (human settlement) sehingga memberikan manfaat bagi individu yang berdiam di kawasan permukinan ("in such a way as to make individuals better able to act on their capabilities and to develop them" - Fischler, 2012: 110). Seperti yang terlihat dalam Gambar 2 dan 3, arahan pemanfaatan ruang yang termaktub dalam rencana detail tata ruang pada empat kota tersebut seolah hanya mengikuti pola tata ruang yang ada pada saat ini. Tidak ada perubahan signifikan yang dikonsepsikan dalam dokumen rencana pada kurun 10-20 tahun yang akan datang. Dengan skenario yang seperti itu, pada masa yang akan datang belum tentu kondisi tata ruang akan menjadi lebih bagus, apapun perkembangannya.

Tabel 4 Pernyataan Tujuan Perencanaan Kota Kecil di Empat Kabupaten

\begin{tabular}{|c|c|c|}
\hline Kota & Tujuan Perencanaan & Keterangan/Catatan \\
\hline Ambarawa & - & $\begin{array}{l}\text { Tidak terdapat } \\
\text { pernyataan tujuan dalam } \\
2 \text { dokumen rencana } \\
\text { Ambarawa }\end{array}$ \\
\hline Ampel & $\begin{array}{l}\text { Mewujudkan Kecamatan Ampel sebagai kawasan industri, } \\
\text { dan perdagangan jasa, serta pertanian yang berwawasan } \\
\text { lingkungan dan berorientasi pada konservasi alam }\end{array}$ & \\
\hline Delanggu & $\begin{array}{l}\text { Mewujudkan ruang kecamatan yang dapat meningkatkan } \\
\text { kesejahteraan masyarakat yang berbasis pada sektor } \\
\text { pertanian, perdagangan dan jasa, dengan prinsip } \\
\text { pembangunan berkelanjutan }\end{array}$ & \\
\hline Muntilan & $\begin{array}{l}\text { Mewujudkan Kecamatan Muntilan sebagai pusat pelayanan } \\
\text { kegiatan pemerintahan, perdagangan dan jasa, serta sosial } \\
\text { ekonomi, yang didukung oleh pengembangan kegiatan } \\
\text { industri rumah tangga pendukung pariwisata, pertanian dan } \\
\text { permukiman yang berbasis potensi dan budaya lokal, } \\
\text { berwawasan lingkungan serta berbasis mitigasi bencana }\end{array}$ & \\
\hline
\end{tabular}

Sumber: Diolah dari dokumen RDRK 4 kabupaten, 2016

Gaya perencanaan yang "konservatif" ini merupakan salah satu kelemahan utama pendekatan master planning (rencana induk) dalam perencanaan tata ruang. Balbo (1993) berargumen bahwa kelemahan atau "kegagalan" ini terjadi karena pendekatan perencanaan induk kurang atau bahkan tidak mengemukakan dengan jelas dari mana sumberdaya bisa diperoleh untuk bisa merealisasikan tujuan perencanaan dan tata ruang kota yang diinginkan. Dalam kasus perencanaan tata ruang di empat kota kecil ini, terdapat bahasan mengenai indikasi program pada bagian akhir. Meskipun sudah ada indikasi program, dokumen rencana hanya mengemukannya secara indikatif dan tidak ada panduan yang lebih rinci lagi berapa banyak kebutuhan fiskal yang diperlukan untuk mengisi tahapan pembangunan menuju kondisi terencana. Pada sisi inilah sebenarnya relevansi pengelolaan kota itu menjadi penting.

Berkurangnya kapasitas sumber dana pembangunan dalam pengelolaan kota-kota kecil belum sejalan dengan kapasitas kelembagaan. Dengan implementasi UU Pemerintahan Daerah (UUPD) yang baru, banyak perubahan tidak saja numenklatur organ pemerintah daerah, tetapi juga perubahan dalam pembagian urusan antara pemerintah 
kabupaten, provinsi dan pemerintah pusat UUPD baru ini juga memberikan kewenangan yang lebih besar kepada pemerintahan kecamatan.

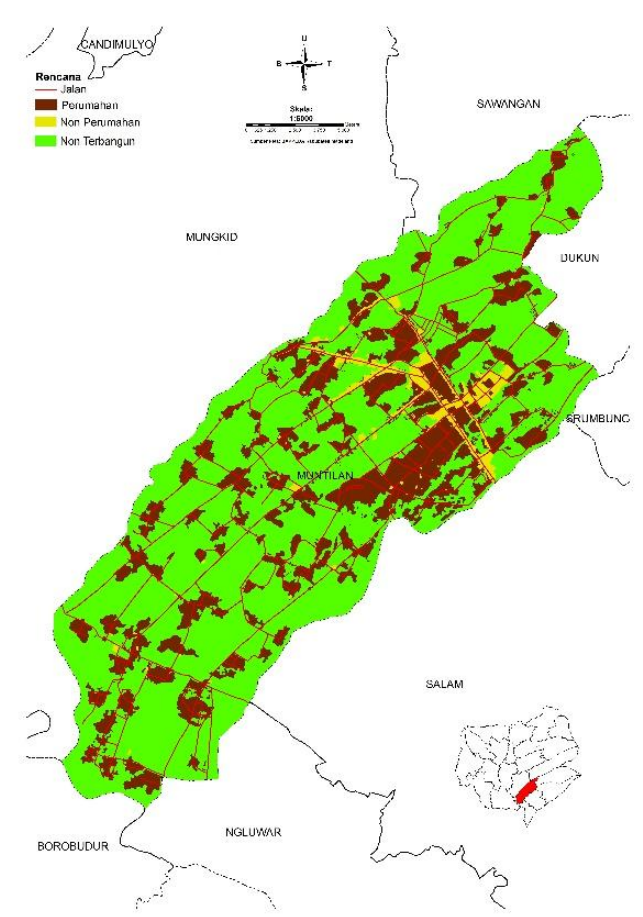

Muntilan

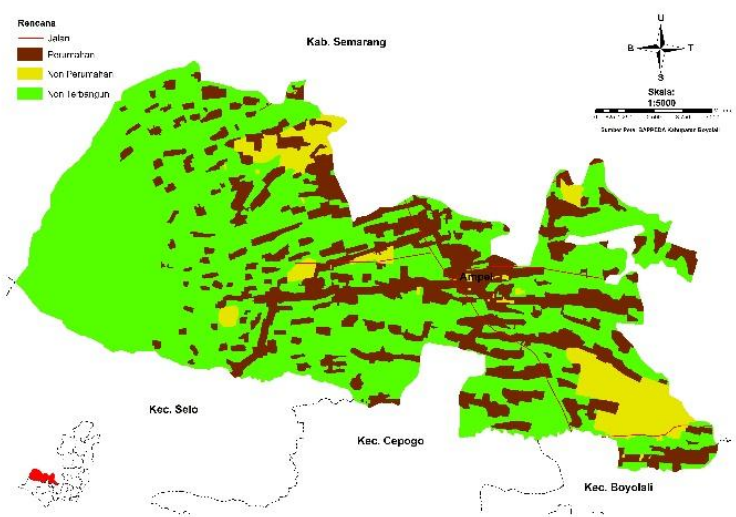

Ampel

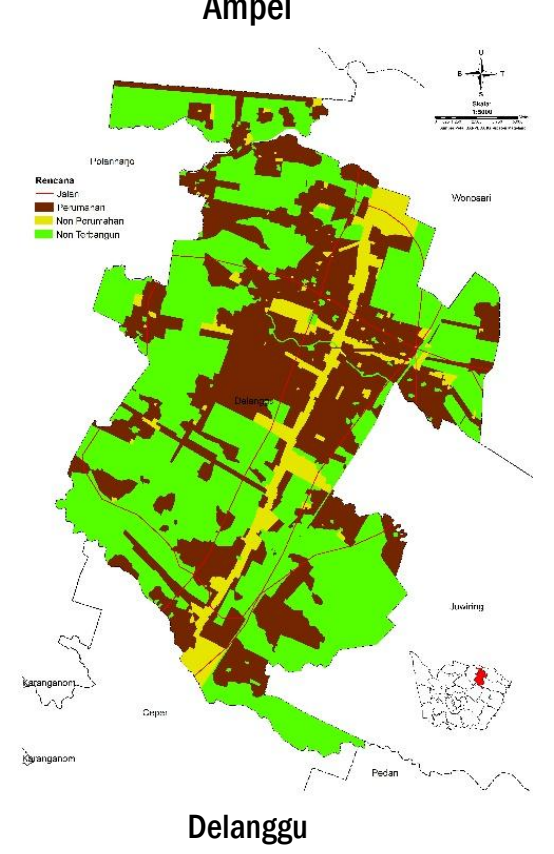

Sumber: RDTRK Empat Kota, 2016

Gambar 2 Rencana Pemanfaatan Ruang Empat Kota Kecil

Perubahan ini membuka peluang baru pengelolaan kawasan perkotaan pada tingkat kecamatan. Meskipun begitu, belum banyak perubahan yang terjadi pada pengelolaan kota-kota kecil di wilayah Joglosemar. Dalam diskusi di forum Musrenbang kecamatan pada periode Februari 2016 diperoleh kesan bahwa peran pemerintah kabupaten masih 
dominan dalam proses perumusan kebijakan dan penyusunan prioritas pembangunan. Ma'rif, Nugroho, dan Wijayanti (2010) mengatakan bahwa forum Musrenbang masih belum efektif sebagai wadah bagi bertemunya berbagai maam kepentingan. Argumentasi yang sama juga dikemukakan oleh Purba (2011), Antlöv dan Wetterberg (2011), dan Sopanah (2012) yang pada intinya mengatakan bahwa forum Musrenbang ini, meskipun mulai menunjukkan perbaikan sebagai forum multistakeholder, masih belum efektif sebagai bagian dari proses perumusan kebijakan pembangunan.

Dalam forum Musrenbang yang berlangsung di empat kota, pembahasan mengenai rencana tata ruang, baik rencana tata ruang wilayah maupun rencana detail tata ruang kecamatan/kota tidak dilakukan. Proses diskusi usulan pembangunan dilakukan dalam kelompok dan didasarkan pada daftar usulan yang telah dirangkum dalam bentuk tabel hasil kompilasi yang dilakukan pada tingkat kabupaten atau kecamatan. Pada tabel tersebut telah tertera kagiatan apa yang dilakukan, alokasi usulan dana pembangunan yang dibutuhkan, serta lokasi di mana kegiatan tersebut akan dilakukan. Para peserta yang terbagi ke dalam kelompok lalu memberikan tanggapan dan fasilitator, yang umumnya aparatur kecamatan atau kabupaten, merangkumnya dan menyajikan hasil diskusi kelompok tersebut ke dalam forum umum lagi. Proses yang berjalan memang sangat pragmatis karena tujuan utamanya adalah meneguhkan daftar kegiatan yang telah disusun sebelumnya untuk kemudian dibawa pada forum Musrenbang pada tingkat kabupaten.

Melihat proses yang terjadi dalam tataran praktek tersebut, terdapat kecenderungan bahwa proses perencanaan pembangunan tidak berawal dari pendalaman terhadap arahan-arahan yang tertera dalam rencana tata ruang wilayah. Sementara itu, proses perencanaan tata ruang ruang yang dilakukanpun cenderung berjalan searah dan menjadi kewenangan lembaga pemerintah pada tingkat kabupaten. Umumnya penyiapan dokumen perencanaan dilakukan oleh Bappeda atau Dinas dengan bantuan konsultansi dari pihak ketiga. Konsultan ini mengerjakan semua pekerjaan yang bersifat teknokratik sampai tersusun sebuah dokumen rencana. Proses berikutnya adalah beberapa kali "konsultasi publik" yang umumnya dilakukan pada tingkat kabupaten. Pendekatan yang seperti ini sudah berjalan secara menerus dan dilakukan berdasarkan seperangkat pedoman yang diterbitkan oleh lembaga pemerintah pusat, yakni Kementerian Pekerjaan Umum. Dalam kasus pada wilayah atau kawasan yang dianggap mempunyai nilai strategis, proses perumusan dokumen rencana tersebut dilaksanakan oleh pemerintah pusat secara langsung.

\section{Proses Perencanaan dan Pembangunan}

Proses perencanaan tata ruang yang berlaku di Indonesia termasuk ke dalam model atau pendekatan perencanaan statutori (statutory planning). Davidson (1996) mengatakan bahwa perencanaan statutori adalah perencanaan yang dibentuk dan dirinci substansinya oleh peraturan - "set up and specified by law" (Davidson, 1996: 453). Model perencanaan seperti ini banyak diterapkan di negara-negara maju dan diadopsi oleh negara berkembang pasca Perang Dunia II, meskipun belakangan dianggap gagal karena tidak mampu menyelesaikan masalah yang terjadi di kota-kota negara berkembang yang mengalami perkembangan yang cukup pesat (Balbo, 1993; Rakodi, 2001). Perencanaan statutori ini sebenarnya mempunyai kelebihan di antaranya: (1) menghindari adanya proses dan tindakan yang bersifat ad-hoc dalam pengambilan keputusan, sehingga bebas dari kepentingan sepihak; (2) mempunyai basis legal yang kuat (Davidson, 1996). Namun, model ini juga mempunyai banyak kelemahan (Balbo, 1993; Davidson, 1996). Di antara banyak kelemahan itu, satu yang menonjol adalah perencanaan menjadi instrumen yang tidak efektif jika ada kelemahan dalam pemerintahan serta sikap penghormatan terhadap hukum rendah (Davidson, 1996). 


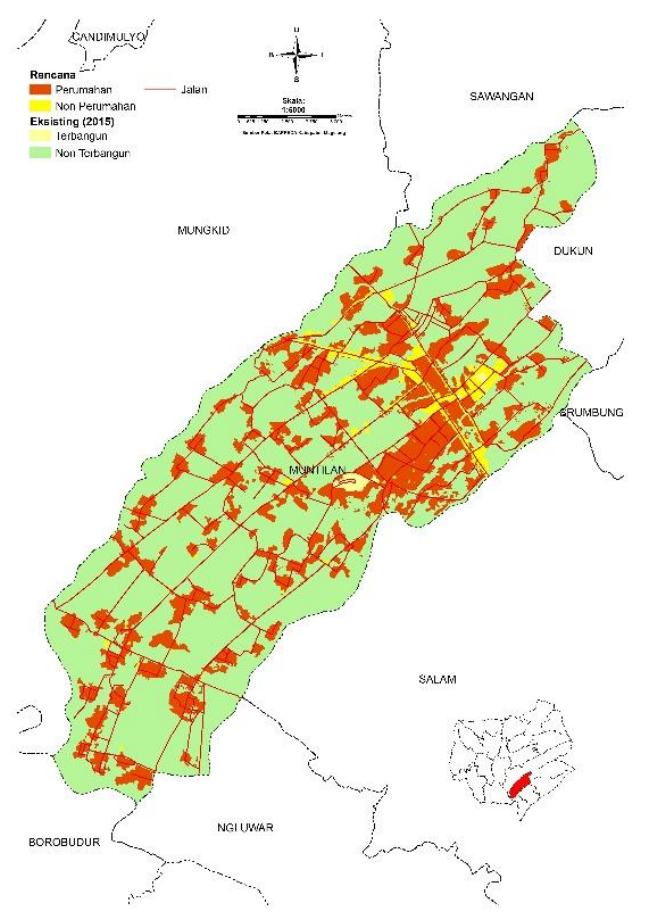

Muntilan

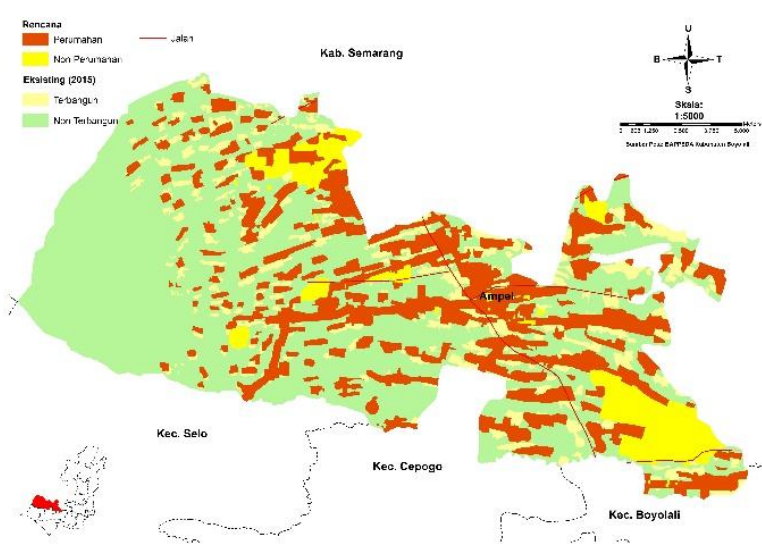

Ampel

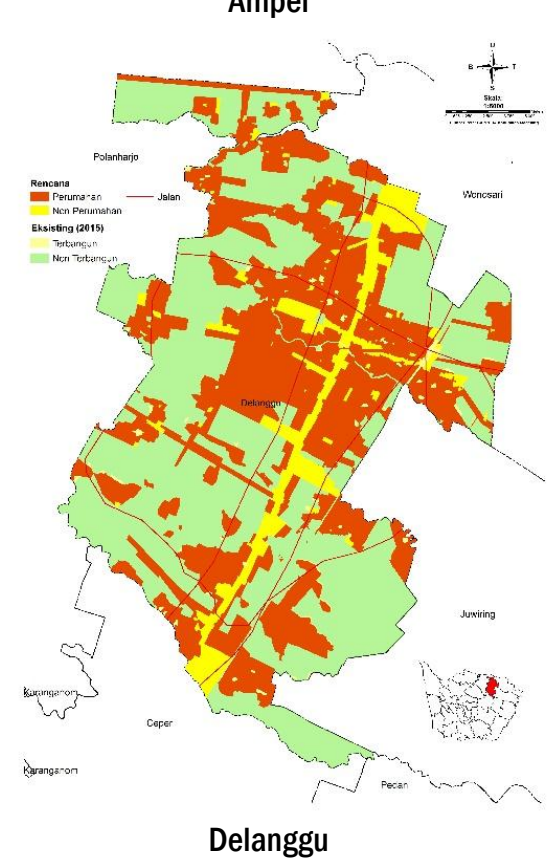

Sumber: RDTRK Empat Kota, 2016

Gambar 3 Perbandingan Rencana dengan Kondisi Saat Ini

Apakah model perencanaan ini bisa tepat digunakan sebagai bagian dari pengelolaan kota kecil, di Indonesia khususnya? Beberapa studi di negara maju memberikan penjelasan bahwa perencanaan komprehesif dalam bentuk rencana induk ini berhasil. Ihlanfeldt (2009) dalam penelitiannya di Amerika Serikat menyatakan bahwa rencana induk kota berhasil mengatur kota sehingga terjadi kenaikan nilai properti dan lahan. Namun sebaliknya, pada kasus negara berkembang seperti yang dikemukakan oleh Sharifi dkk. (2014) dalam penelitiannya di Laos, perencanaan induk atau komprehensif ini 
gagal dalam mengelola pertumbuhan kota yang cepat, sehingga perkembangan yang ada justru mengarah kepada pertumbuhan yang tidak terencana.

Berangkat dari hal tersebut, efektivitas perencanaan komprehensif atau sinoptik dalam bentuk rencana induk yang diberlakukan pada kota kecil dengan perkembangan yang relatif lambat atau stagnan bisa saja sangat rendah. Kota-kota kecil yang menjadi kasus dalam penelitian ini umumnya berkembang dengan laju pertumbuhan yang tidak cepat, khususnya perubahan kawasan terbangun, sehingga tidak ada kebutuhan mendesak bagi kota kecil tersebut untuk pengaturan yang bersifat jangka panjang dengan gagasan besar.

Bentuk perencanaan lain yang lebih mampu mengajak peran masyarakat untuk mengenali kebutuhan pembangunan kotanya sepertinya akan lebih efektif dalam mengelola perkembangan kota di masa yang akan datang. Perencanaan yang berbasis pada konsensus dan bersifat kolaboratif bisa menjadi alternatif. Woltjer (2008) mengatakan bahwa perencanaan konsensus mempunyai tiga karakteristik yang menjadikannya potensial menjadi solusi untuk mengatasi ketidakefektifan rencana komprehensif. Ketiga karakteristik tersebut adalah: (1) adanya proses kolaboratif dan belajar bersama; (2) adanya proses tawar-menawar (bargaining) dan negosiasi, serta (2) adanya proses persuasi dan pembentukan keinginan bersama (Woltjer, 2008: 26). Dalam kerangka perencanaan konsensus, ketiga proses tersebut tidak harus mengubah total pendekatan perencanaan, melainkan hanya memperkuat pendekatan yang ada sehingga ada jembatan antara berbagai pendekatan itu sehingga rencana bisa lebih efektif.

\section{Pelaku-pelaku Pengelolaan}

Pelaku dalam pengelolaan perkotaan tidak dapat dilepaskan dari pendekatan perencanaan yang diterapkan dalam praktek. Sebagaimana dibahas sebelumnya, pendekatan perencanaan sinoptik atau komprehensif mempunyai satu karakteristik penting yakni kuatnya peran pemerintah dalam proses perencanaan dan perumusan kebijakan. Pada kasus perencanaan tata ruang di kota-kota kecil di wilayah Jolgosemar ini, bahkan pemerintah pusat yang secara lokasi jauh dari tempat di mana obyek perencanaan berada masih mempunyai peran yang sangat sentral. Peran sentral ini bahkan mencakup juga pada hal-hal yang bersifat teknis seperti tentang koreksi peta dasar. Semua peta dasar yang dipergunakan untuk penyusunan rencana tata ruang wilayah kabupaten dan rencana detail tata ruang wilayah kota harus dikonsultasikan kepada Badan Informasi Geospasial (BIG) di Jakarta untuk menyesuaikan dengan standar baru perpetaan (Wawancara kepada staf Bappeda di Empat Kabupaten, 2016).

Dari pendalaman yang dilakukan terhadap dokumen peraturan dan wawancara di lapangan, diperoleh bahwa terdapat setidaknya 11 lembaga/organisasi yang berperan dalam pengelolaan perkotaan, sebagian besar merupakan lembaga pemerintah (Tabel 5). Dalam praktek, lembaga-lembaga tersebut jarang atau bahkan tidak pernah bertemu dalam sebuah forum atau wadah dalam kurun waktu dan tempat tertentu. Diskusi dan komunikasi yang terjadi hanya melibatkan beberapa lembaga saja, dalam frekuensi yang terbatas. Sebagi contoh, hubungan antara lembaga pada tingkat kabupaten dengan provinsi dan pusat terjadi ketika diperlukan konsultasi tentang kebijakan tertentu yang harus dikerjakan oleh daerah. Hubungan yang terjadi antara swasta (konsultan/kontraktor) dengan lembaga pemerintah hanya bersifat kontraktual yang berjangka waktu pendek dan berbasis kegiatan. Keterkaitan kuat memang terjadi antara pemerintah desa/kelurahan dengan kecamatan dan lembaga pemerintah tingkat kabupaten, sebagai bagian dari sistem formal yang berlaku. 
Tabel 5 Pelaku Pengelolaan Perkotaan di Kota Kecil

\begin{tabular}{|c|c|c|c|}
\hline No & Lembaga & Peran & Keterangan \\
\hline 1 & $\begin{array}{l}\text { Kementerian PUPR/ } \\
\text { Kementerian ATR }\end{array}$ & $\begin{array}{l}\text { - Merumuskan pedoman penataan ruang } \\
\text { - Mensupervisi aspek teknis penataan ruang } \\
\text { - Menyetujui substansi peraturan daerah tentang rencana } \\
\text { tata ruang }\end{array}$ & $\begin{array}{l}\text { Sejak } 2014, \\
\text { kewenangan } \\
\text { bidang } \\
\text { penataan }\end{array}$ \\
\hline 2 & $\begin{array}{l}\text { Kementerian Dalam } \\
\text { Negeri }\end{array}$ & $\begin{array}{l}\text { - Mensurvisi proses penyusunan peraturan daerah tentang } \\
\text { rencana tata ruang } \\
\text { - Merumuskan pedoman perencanaan pembangunan } \\
\text { daerah }\end{array}$ & $\begin{array}{l}\text { ruang } \\
\text { dialihkan ke } \\
\text { Kementerian } \\
\text { Agraria dan } \\
\text { Tata Ruang }\end{array}$ \\
\hline 3 & $\begin{array}{l}\text { Badan Informasi } \\
\text { Geospasial }\end{array}$ & Menyetujui aspek teknis perpetaan & \\
\hline 4 & Bappeda Provinsi & $\begin{array}{l}\text { Menyetujui substansi teknis peraturan daerah tentang } \\
\text { rencana tata ruang }\end{array}$ & \\
\hline 5 & Bappeda Kabupaten & $\begin{array}{l}\text { - Merumuskan dan menyusun dokumen rencana tata ruang } \\
\text { - Merumuskan dan menyelenggarakan Musrenbang }\end{array}$ & \\
\hline 6 & Dinas PU/sejenis & Menerbitkan ijin pembangunan & \\
\hline 7 & Kecamatan & Melakukan sosialisasi dan diseminasi informasi & \\
\hline 8 & Desa & $\begin{array}{l}\text { - Merencanakan anggaran dan melaksanan kegiatan } \\
\text { pembangunan } \\
\text { - Melakukan pencatatan/administrasi urusan pemerintahan }\end{array}$ & \\
\hline 9 & Kelurahan & Melakukan pencatatan/administrasi urusan pemerintahan & \\
\hline 10 & Konsultan/kontraktor & $\begin{array}{l}\text { - Membantu dinas/badan menyusun dokumen } \\
\text { perencanaan } \\
\text { - Melaksanakan kegiatan pembangunan }\end{array}$ & \\
\hline 11 & Fasilitator desa & $\begin{array}{l}\text { - Mendampingi desa dalam pengelolaan dana } \\
\text { pembangunan }\end{array}$ & $\begin{array}{l}\text { Eks kegiatan } \\
\text { PNPM } \\
\text { Mandiri yang } \\
\text { didanai oleh } \\
\text { Bank Dunia }\end{array}$ \\
\hline 12 & Masyarakat & $\begin{array}{l}\text { - Menerima hasil kegiatan } \\
\text { - Memberikan saran/pendapat dalam forum konsultasi } \\
\text { pembangunan }\end{array}$ & \\
\hline
\end{tabular}

Sumber: Olahan dari telaah dokumen, wawancara, 2016

Kondisi pengelolaan yang seperti ini memberikan gambaran tentang adanya dua hal penting. Pertama, ada kemungkinan bahwa pengelolaan perkotaan berjalan secara otonom, di mana pengelolaan yang ada berlangsung secara alamiah seolah tanpa ada kehadiran pemerintah dalam sistem pengolaan yang terjadi. Dengan kata lain, tidak ada sistem lini pengelolaan di mana sebuah lembaga bertanggung jawab terhadap hal tertentu dan berkoordinasi dengan lembaga lain jika diperlukan. Kedua, ada juga kemungkinan pengelolaan bersama di antara lembaga pemerintah yang ada, di mana para pelaku yang terlibat dalam pengelolaan itu berkomunikasi dalam proses pengambilan keputusan. Forum ini adalah BKPRD (Badan Koordinasi Penataan Ruang Daerah), sebuah forum yang dilembagakan untuk merespon hal-hal yang menyangkut perijinan dan permasalahan yang bersifat krusial di kabupaten. 


\section{Model Pengelolaan Kota Kecil}

Dari pemahaman terhadap temuan penelitian pada kasus di wilayah Joglosemar, pengelolaan kota bersifat terpecah (fragmented). Setidaknya terdapat empat pecahan pengelolaan perkotaan di wilayah Joglosemar ini. Fragmentasi pertama berhubungan dengan keterkaitan antara dokumen perencanaan. Rencana tata ruang wilayah kabupaten telah merumuskan arahan peran kota-kota kecil dalam pengembangan wilayah melalui penetapan status dan fungsi kota. Arahan ini seharusnya ditindaklanjuti dalam rencana detail dengan menjelaskan elemen kota penting apa yang seharusnya ada dalam kota untuk bisa menjalankankan fungsi dan perannya dalam pengembangan wilayah. Koneksi ini tidak terjadi karena proses penyusunan rencana detail tata ruang kota menggunakan prosedur baku di mana pemerintah daerah tidak punya cara lain kecualinya mengikuti semua aturan dan pedoman itu. Sebagai akibatnya, terdapat ketidaksinkronan antara substansi rencana umum dengan rencana detail.

Gambar 4 memaparkan bagaimana kondisi yang ada dan bagaimana kondisi yang seharusnya. Model ini merupakan modifikasi dari gagasan teoretis yang dikemukakan oleh Davidson (1996) tentang bagaimana keseluruhan pengelolaan kota yang dimulai dengan penyusunan dokumen rencana hingga tercipta hasil-hasil perencanaan sesuai dengan yang direncanakan itu. Perencanaan yang baik adalah perencanaan yang dilaksanakan sehingga terwujud kondisi yang terencana sebagaimana yang diarahkan. Untuk mewujudkan gagasan perencanaan itu, sedikitnya ada empat "saluran" yang bisa dipergunakan secara bersamaan. Keempat jalur pelaksanaan ini masing-masing membutuhkan pelaku utama sebagai penentunya, dimulai dari individu sampai dengan pemerintah atau negara.

Pada setiap saluran tersebut seharusnya pembagian peran antar pelaku dalam proses pembangunan bisa dilakukan secara seimbang, mengingat cakupan permasalahan kota kecil relatif lebih sederhana dengan skala yang terbatas, yang berbeda dengan kota-kota yang lebih besar (diagram b dan c Gambar 4). Dalam kondisi faktual (diagram a Gambar 4), yang terjadi adalah dominannya saluran pedoman dan kontrol yang dilakukan oleh pemerintah. Dominasi pemerintah hampir pada semua hal mengakibatkan kurang berperannya masyarakat, baik dalam tataran individu dan kelompok. Dalam lingkungan proses pengambilan keputusan yang seperti ini pengelolaan kota secara keseluruhan tidak akan berjalan dengan efektif dalam mengarahkan pembangunan kota kecil menuju kondisi yang diinginkan. Selain itu, situasi yang seperti ini bisa mengarah kepada munculnya praktek-praktek pengelolaan perkotaan pada skala kecil yang bisa menjadikan kota semakin terpecah (fragmented). Bahkan dalam jangka panjang, tradisi ini bisa mengarah kepada munculnya pendekatan 'radical planning' atau 'covert planning.' Ini adalah sebuah respon dari menguatnya peran pemerintah dalam proses perencanaan dan pembangunan kota (Watson, 2009; Beard, 2002).

\section{KESIMPULAN}

Yang terjadi pada kasus perkembangan dan pengelolaan kota kecil di wilayah Joglosemar mengindikasikan adanya pengelolaan perkotaan yang berjalan tidak efektif. Perlakukan yang diberikan dalam pengelolaan kota kecil seolah sama dengan perlakuan pada kota besar yang bersifat otonom. Terdapat perbedaan yang sangat mendasar antara kota-kota yang berstatus sebagai daerah otonom kota (municipality) dengan kota-kota kecil yang secara fakual merupakan kawasan perkotaan kecil yang menjadi bagian dari wilayah administrasi kecamatan dan berada dalam kewenangan pemerintah kabupaten dalam pengelolaan urusan pemerintahan maupun pembangunan. Dalam struktur yang seperti ini, kota kecil tidak mempunyai organ pemerintahan tersendiri yang mempunyai kewenangan pengelolaan perkotaan sebagaiman halnya yang dimiliki oleh kota-kota dengan status otonom. 


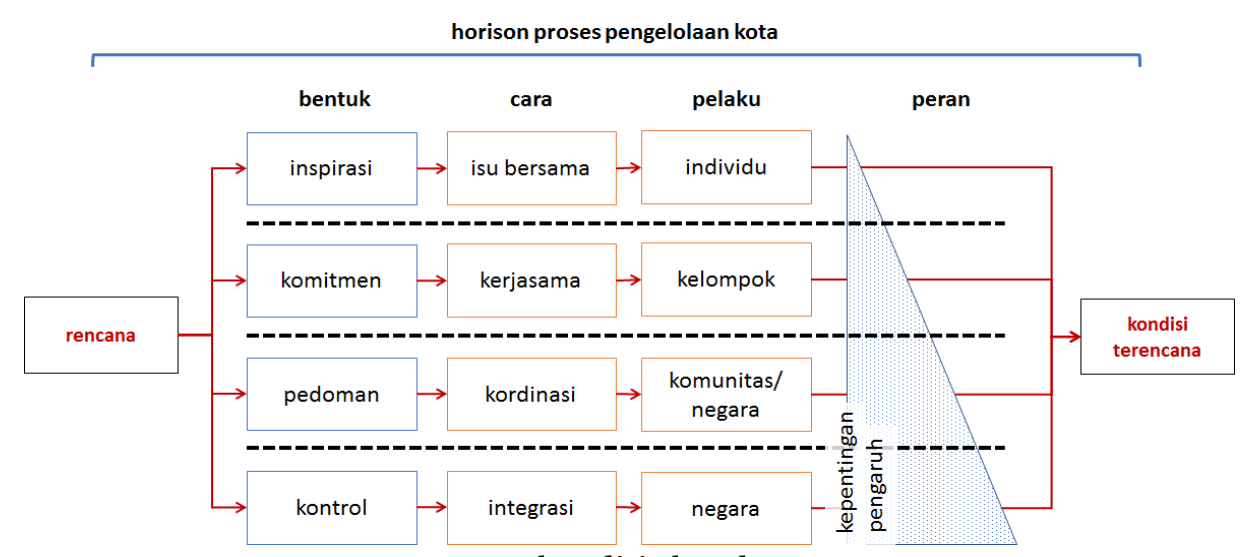

(a) kondisi aktual

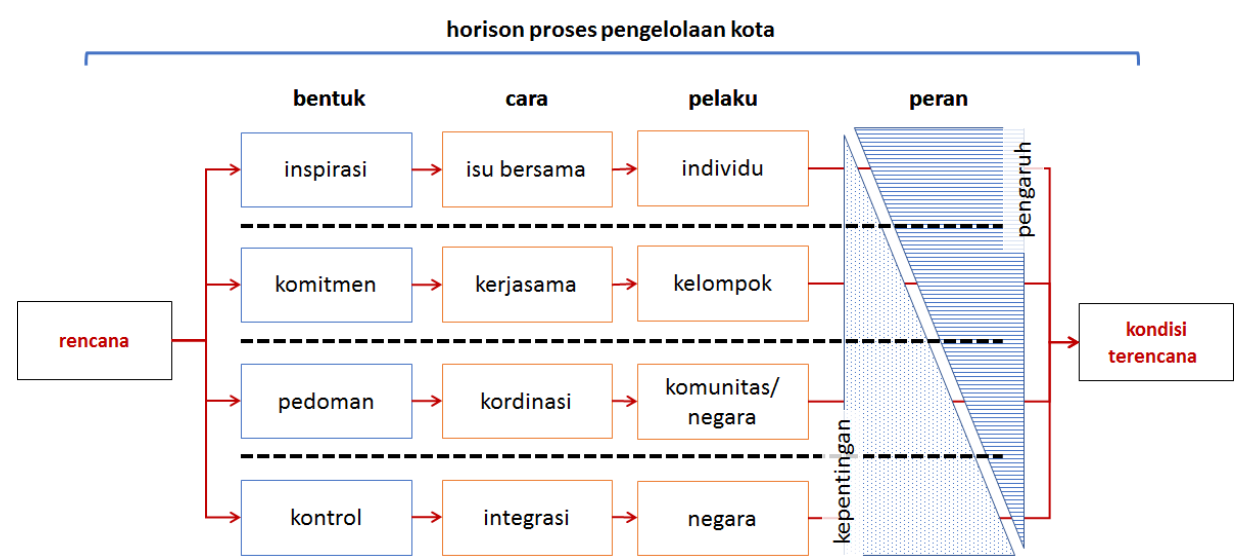

(b) kondisi seharusnya tipe 1

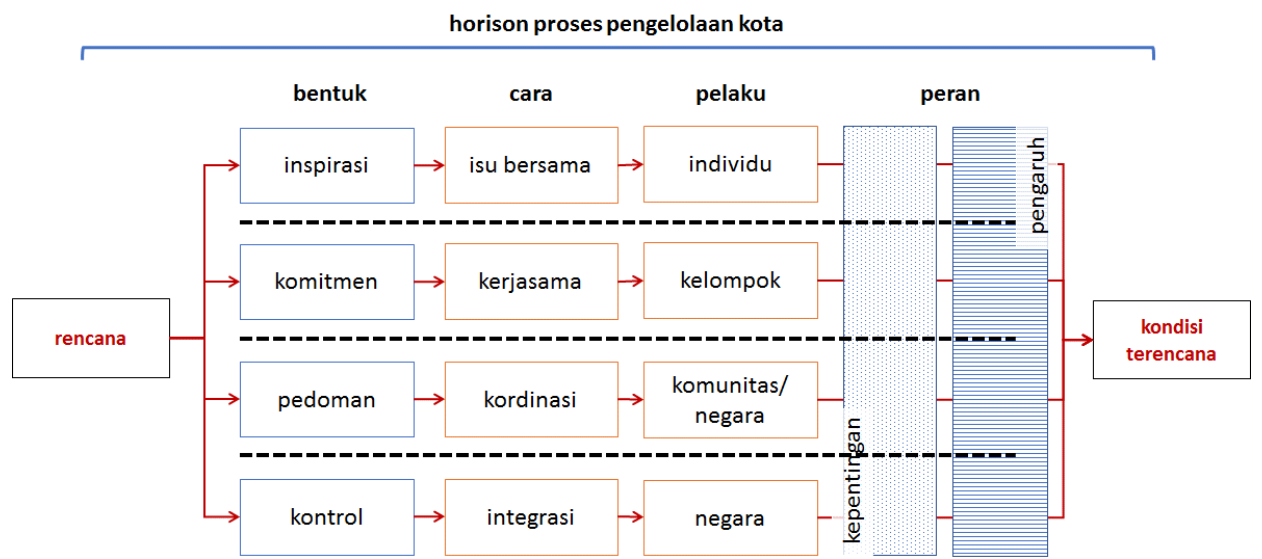

(c) kondisi seharusnya tipe 2

\section{Gambar 4 Model Pengelolaan Kota Kecil}

Pada saat sekarang, pola pengelolaan perkotaan kecil di wilayah Joglosemar masih sangat bergantung kepada pemerintah kabupaten. Bahkan pada aspek perencanaan tata ruang perkotaan, peranan pemerintah pusat juga dominan karena menjadi penentu proses dan produk perencanaannya. Peran masyarakat lokal dan pemerintah kecamatan di mana kawasan perkotaan kecil itu berada masih sangat kecil, kecuali pada beberapa hal yang 
berkaitan dengan urusan administrasi yang didelegasikan kepada pemerintah kecamatan. Dengan pendekatan yang demikian itu, pengelolaan perkotaan cenderung seragam antara satu kota dengan kota lainnya. Keseragaman ini dimulai dari proses perencanaan tata ruang, di mana prosedur yang dipakai di dalam praktek perencanaan telah dibakukan, tidak saja dari sisi substansi rencananya tetapi juga cara analisis dan prosedur penetapan rencana menjadi dokumen peraturan yang mengikat.

Pendekatan perencanaan statutori dengan model perencanaan komprehensif atau sinoptik ini berpotensi untuk menghilangkan elemen kelokalan yang menjadi penciri kota kecil. Di samping itu, perencanaan komprehensif bisa tidak sesuai dengan kebutuhan pengembangan kota kecil. Berbeda dengan kota besar atau metropolitan, pengembangan kota kecil tidak memerlukan gagasan perencanaan yang bersifat grand design karena fungsi pokoknya sebagai pusat permukiman hanya membutuhkan arahan tertentu untuk menfungsikan kota sebagai tempat pemenuhan kebutuhan dasar bagi warganya. Selain kebutuhan dasar tersebut, elemen penting dari perencanaan yang dibutuhkan kota kecil adalah fasilitas dan prasarana pendukung yang memperkuat fungsinya sebagai kota perantara, khususnya bagi pengembangan kawasan perdesaan di sekitarnya. Kebutuhankebutuhan ini yang belum sepenuhnya terakomodasi dalam perencanaan sinoptik yang selama ini dipraktekkan pada kota-kota kecil di wilayah Joglosemar.

\section{UCAPAN TERIMA KASIH}

Sebagian dari kegiatan penelitian ini dibiayai oleh Hibah Penelitian Dasar pada Departemen Perencanaan Wilayah dan Kota, Fakultas Teknik, Universitas Diponegoro tahun anggaran 2015 dan 2016. Penulis mengucapkan terimakasih kepada Pengelola Departemen atas bantuan pendanaan tersebut. Terimakasih juga disampaikan kepada reviewer artikel atas koreksi dan kritik yang konstruktif. Namun demikian, semua tanggung jawab substansi penulisan sepenuhnya ada pada penulis sendiri.

\section{DAFTAR PUSTAKA}

Antlöv, H., \& Wetterberg, A. (2011). Citizen engagement, deliberative spaces and the consolidation of a postauthoritarian democracy: The case of Indonesia. Visby (Sweden): The International Center for Local Democracy, Working Paper, (8).

Balbo, M. (1993). Urban planning and the fragmented city of developing countries, Third World Planning Review, 15 (1), 23 - 34.

Beard, V. A. (2002). Covert planning for social transformation in Indonesia. Journal of Planning Education and Research, 22(1), 15-25.

Bell, D. dan Jayne, M. (2006). Small Cities: Urban Experience Beyond the Metropolis. Routledge.

Bell, D. dan Jayne, M. (2009). Small cities? Towards a research agenda, International Journal of Urban and Regional Research, 33 (3), 683-699.

Brower, D.J. et. al (1984). Managing Development in Small Town. Washington: Planner Press.

Davidson, F (1996). Planning for performance: requirements for sustainable development, Habitat International, 20 (3), 445-462.

Devas, N dan Rakodi, C (eds.) (1993). Managing Fast Growing Cities: New Approaches to Urban Planning. John Wiley and Sons.

Fahmi, F. Z., Hudalah, D., Rahayu, P., \& Woltjer, J. (2014). Extended urbanization in small and medium-sized cities: The case of Cirebon, Indonesia, Habitat International, 42, 1-10.

Firman, T. (2003). Potential impacts of Indonesia's fiscal decentralisation reform on urban and regional development: Towards a new pattern of spatial disparity. Space and Polity, 7(3), 247-271.

Firman, T. (2016). The urbanisation of Java, 2000-2010: towards 'the island of mega-urban regions'. Asian Population Studies, 13(1), 50-66.

Firman, T., Kombaitan, B., \& Pradono, P. (2007). The dynamics of Indonesia's urbanisation, 1980—2006, Urban Policy and Research, 25(4), 433-454. 
Fischler, R. (2012). Fifty theses on urban planning and urban planners. Journal of Planning Education and Research, 32(1), 107-114.

Friedmann, J. (1971). The future of comprehensive urban planning: A critique. Public Administration Review, 31(3), 315-326.

Ginsburg, N. S., Koppel, B., \& McGee, T. G. (Eds.). (1991). The Extended Metropolis: Settlement Transition in Asia. University of Hawaii Press.

Giyarsih, S. R. (2010). Pola spasial transformasi wilayah di Koridor Yogyakarta-Surakarta, Forum Geografi, 24(1), 28 - 38.

Harsono (1992). Hukum Tata Negara: Pemerintahan Lokal dari Masa ke Masa. Penerbit Liberty.

Hill, H., \& Vidyattama, Y. (2016). Regional development dynamics in indonesia before and after the "big bang'decentralization. The Singapore Economic Review, 61(02), 1640027-(1-26).

Hudson, B. M., Galloway, T. D., \& Kaufman, J. L. (1979). Comparison of current planning theories: Counterparts and contradictions. Journal of the American Planning Association, 45(4), 387-398.

Ihlanfeldt, K. R. (2009). Does comprehensive land-use planning improve cities? Land Economics, 85(1), 74-86.

Innes, J. E. (1996). Planning through consensus building: a new view of the comprehensive planning ideal. Journal of the American Planning Association, 62(4).

Keiner, M. et al. (eds.) (2005). Managing Urban Futures: Sustainability and Urban Growth in Developing Countries. Aldershot: Ashgate.

Ma'rif, S., Nugroho, P., \& Wijayanti, L. (2010). Evaluasi efektivitas pelaksanaan musyawarah perencanaan pembangunan (musrenbang) Kota Semarang. Riptek, 4(11), 53-62.

Mardiansjah, F. (2007). Urbanisasi Wilayah Berkelanjutan dan Kebijakan Pembangunan Perkotaan di Indonesia: Studi Kasus dari Tiga Kabupaten yang Terurbanisasi Tercepat di Pulau Jawa. Laporan Penelitian Hibah Penelitian Beasiswa Unggulan.

McGill, R. (1998). Viewpoint urban management in developing countries, Cities, 15 (6), 463-471.

Niessen, N. (1999). Municipal Government in Indonesia: Policy, Law, And Practice of Decentralization and Urban Spatial Planning (No. 77). Research School CNWS, School of Asian, African, and Amerindian Studies, Universiteit Leiden.

Obeng-Odoom, F. (2012). On the origin, meaning, and evaluation of urban governance. Norsk Geografisk Tidsskrift-Norwegian Journal of Geography, 66(4), 204-212.

Ofori-Amoah, B. (2007). Beyond the Metropolis: Urban Geography As If Small Cities Mattered. University Press of America.

Oliveira, V., \& Pinho, P. (2010). Evaluation in urban planning: advances and prospects. Journal of Planning Literature, 24(4), 343-361.

Pacione, M. (2009). Urban geography: A global perspective. Routledge.

Pieterse, E. (2000). Participatory Urban Governance. Nairobi: UNCHS (Habitat).

Purba, R. E. (2011). Public participation in development planning: a case study of Indonesian Musrenbang. International Journal of Interdisciplinary Social Sciences, 5(12).

Rakodi, C (2001). Forget planning, put politics first? Priorities for urban management in developing countries, Journal of Applied Geoinformation Sciences, 3 (3), 209 - 223.

Reyansih, (2003). Aspek pengaturan penataan raung dalam Undang-undang Otonomi Daerah, dalam DJPR-PU, Beberapa Ungkapan Sejarah Penataan Ruang Indonesia 1948-2000, DJPR-PU, 189-201.

Rutz, W. (1987). Cities and Town in Indonesia: Their Development, Current Positions and Functions with Regard to Administration and Regional Economy. Gedruder Borntraeger.

Setyono, J.S. (2011). Small and medium urban centers in Central Java, Indonesia: questioning the role of planning and governance in development process. Prosiding International Conference on the Future of Urban and Peri-urban Area, Yogyakarta, 11-12 Juli 2011, 241-251.

Sharifi, A., Chiba, Y., Okamoto, K., Yokoyama, S., \& Murayama, A. (2014). Can master planning control and regulate urban growth in Vientiane, Laos? Landscape and Urban Planning, 131, 1-13.

Shawma, N. G. (2012). Perencanaan Tata Ruang dan Implementasinya pada Kota Kecil di Jawa Tengah (Studi Kasus: Kota Muntilan). Tugas Akhir, Jurusan Perencanaan Wilayah dan Kota, Fakultas Teknik, Universitas Diponegoro.

Sopanah, A. (2012). Ceremonial budgeting: public participation in development planning at an Indonesian local government authority. Journal of Applied Management Accounting Research, 10(2), 73-84.

Tacoli, C. (ed.) (2006). The Earthcan Reader in Rural-Urban Linkages. Earthscan Publication. 
Talen, E. (1997). Success, failure, and conformance: an alternative approach to planning evaluation. Environment and Planning B: Planning and Design, 24(4), 573-587.

United Nations. (2015). World Urbanization Prospects 2014: Highlights. United Nations Publications.

van Dijk, M. et al. (eds) (2002). Governing Cities: New Institutional Forms in Developing Countries and Transitional Economies. ITDG Publishing.

van Roosmalen, P. K. (2005). Expanding Grounds, the Roots of Spatial Planning in Indonesia. Airlangga University, dalam Freek Colombijn, Martine Barwegen, Kota Lama, Kota Baru: Sejarah Kota-Kota di Indonesia Sebelum dan Setelah Kemerdekaan, Ombak, 75-117.

Watson, V. (2009). 'The planned city sweeps the poor away...': Urban planning and 21st century urbanisation. Progress in Planning, 72(3), 151-193.

Woltjer, J. (2008). Consensus Planning: The Relevance of Communicative Planning Theory in Dutch Infrastructure Development. Ashgate. 